\title{
Fungsi dan Wewenang Negara dalam Diversi Anak
}

\author{
State Functions and Authorities in Child Diversion
}

\author{
Jamaludin \\ Pembimbing Kemasyarakatan Ahli Muda Balai Pemasyarakatan Kelas II Kendari \\ E-mail: jamal_ludin17@yahoo.co.id
}

La Sensu

Pascasarjana Universitas Halu Oleo

E-mail: lasensu18@gmail.com

Muhammad Sabaruddin Sinapoy

Pascasarjana Universitas Halu Oleo

E-mail: sabaruddinsinapoy@yahoo.com

Deity Yuningsih

Pascasarjana Universitas Halu Oleo

E-mail: deity.yuningsih@yahoo.com

\begin{abstract}
The responsibility of the state in an effort to provide special protection for children in conflict with the law through the delegation of authority to the government is influenced by the characteristics of the duties assigned to it. The task of the government is to follow the duties of the state, namely, to carry out some of the duties of the state as an organization of power as the main obligation that must be carried out by the state is the obligation to respect, obligation to fulfill and an obligation to protect or obliged to control and guarantee the implementation of protection for every individual who is under its jurisdiction. In this study aimed at the process of child diversion as protection of human rights. The objectives of the compilers in this study are how the state's protection for children in the diversion process and what the state's functions and authorities in the diversion process have made to protect children.
\end{abstract}

Keyword: State Authority; Diversion; Protection

Abstrak: Penelitian ini ditujukan pada tanggung jawab negara dalam upaya memberikan perlindungan khusus terhadap anak berhadapan dengan hukum melalui pelimpahan wewenang kepada pemerintah dipengaruhi oleh karakteristik tugas yang dibebankan kepadanya. Tugas pemerintah adalah mengikuti tugas negara yaitu, menyelenggarakan sebagian tugas negara sebagai organisasi kekuasaan sebagai kewajiban utama yang harus diemban negara adalah kewajiban untuk menghormati (to respect), kewajiban untuk memenuhi (to fulfill), dan kewajiban untuk melindungi (to protect) maupun wajib mengontrol dan menjamin berjalannya pelaksanaan perlindungan bagi setiap individu yang berada di bawah yurisdiksinya. Dalam penelitian ini ditujukan pada proses diversi 
anak sebagai perlindungan HAM. Sasaran penyusun dalam penelitian ini adalah bagaimana perlindungan negara terhadap anak dalam proses diversi dan apa fungsi dan wewenang negara dalam proses diversi telah mewujudkan perlindungan kepada anak.

Kata kunci: Wewenang Negara; Diversi; Perlindungan

\section{PENDAHULUAN}

Anak adalah bagian yang tidak terpisahkan dari keberlangsungan hidup manusia dan keberlangsungan sebuah bangsa dan Negara yang secara tegas dinyatakan bahwa negara menjamin hak setiap anak atas kelangsungan hidup, tumbuh, dan berkembang serta atas pelindungan dari kekerasan dan diskriminasi. ${ }^{1}$ Ruang lingkup tanggung jawab negara dalam upaya memberikan perlindungan khusus terhadap anak berhadapan dengan hukum melalui pelimpahan wewenang kepada pemerintah. Tugas pemerintah, menurut Mac Iver dapat digolongkan menjadi tiga yaitu: (1) cultural function, (2) general welfare function, (3) economic control function. ${ }^{2}$ Di Indonesia tugas pemerintah harus sesuai dengan tujuan dibentuknya pemerintah Indonesia menurut pembukaan UUD NRI Tahun 1945 khususnya pada alinea ke4. ${ }^{3}$ Menjalankan tugas sesuai tujuan negara, pemerintah diberikan kewenangan yang tepat dan jelas maksud dan tujuannya. Menurut S.F. Marbun, sifat wewenang pemerintahan yang jelas maksud dan tujuannya itu terikat pada waktu tertentu dan tunduk pada batasan-batasan hukum tertulis dan hukum yang tidak tertulis sedangkan isinya dapat bersifat umum (abstrak). ${ }^{4}$

Negara Indonesia menyadari posisi seorang anak merupakan generasi penerus bangsa, oleh sebab itu untuk menjaga harkat dan martabatnya, anak berhak mendapatkan pelindungan khusus, terutama pelindungan hukum dalam sistem peradilan. Indonesia sebagai negara pihak dalam Konvensi Hak-hak Anak (Convention on the Rights of the Child) dalam Resolusi Majelis Umum PBB No. 44.25, yang telah diratifikasi dalam Keputusan Presiden Nomor 36 Tahun 1990 tanggal 26 Januari Tahun 1990,5 yang mengatur prinsip perlindungan hukum terhadap anak mempunyai kewajiban untuk memberikan perlindungan khusus terhadap anak yang

1 Marlina, Peradilan Pidana Anak di Indonesia, Pengembangan Konsep Diversi dan Restorative Justice, Medan: Refika Aditama, 2012, hlm. XV.

2 Irfan Fachruddin, Pengawasan Peradilan Administrasi terhadap Tindakan Pemerintah, Bandung: PT. Alumni, 2004, hlm. 30.

3 Imam Sukadi, "Tanggung Jawab Negara terhadap Anak Terlantar dalam Operasionalisasi Pemerintah di Bidang Perlindungan Hak Anak", de Jure, Jurnal Syariah dan Hukum, Volume 5 Nomor 2, Desember 2013, hlm. 125.

4 Irfan Fachruddin, Op. cit., hlm. 154.

5 Abintoro Prakoso, Pembaruan Sistem Peradilan Pidana Anak, Surabaya: Laksbang Grafika, 2013, hlm. 4. 
berhadapan dengan hukum. ${ }^{6}$ Kewajiban utama yang harus diemban negara adalah kewajiban untuk menghormati (to respect), kewajiban untuk memenuhi (to fulfill), dan kewajiban untuk melindungi (to protect). ${ }^{7}$ Selain itu, negara juga wajib mengontrol dan menjamin berjalannya pelaksanaan perlindungan bagi setiap individu yang berada di bawah yurisdiksinya. ${ }^{8}$ Posisi dan peran negara sebagai pemberi perlindungan telah menunjukkan bahwa semua aspek yang menyangkut penghormatan, perlindungan, pemenuhan dan pemajuan adalah tanggung jawab negara. ${ }^{9}$ Kemudian, menurut Philip, bahwa pertanggungjawaban negara timbul karena negara merupakan suatu entitas yang berdaulat dan memiliki power untuk melakukan sesuatu atau tidak melakukan sesuatu terhadap warga yang berada di bawah yurisdiksinya. ${ }^{10}$

Secara garis besar, kewajiban negara yang paling mendasar adalah kewajiban untuk menghormati (obligation to respect), kewajiban untuk memenuhi (obligation to fulfill), dan kewajiban untuk melindungi (obligation to protect).11 Selain itu juga, berdasarkan PeraturanPeraturan Minimum Standar Perserikatan Bangsa-Bangsa mengenai Administrasi Peradilan Bagi Anak/The Beijing Rules, Res. No. 40/33 tahun 1985, pelanggaran hukum adalah perilaku apa pun (tindakan atau kelalaian) yang dapat dihukum oleh hukum menurut sistem hukum masing-masing. ${ }^{12}$ Arif Gosita mengatakan bahwa anak wajib dilindungi agar mereka tidak menjadi korban tindakan siapa saja (individu atau kelompok, organisasi swasta maupun pemerintah) baik secara langsung maupun secara tidak langsung. ${ }^{13}$

Menurut F. Sungeng Istanto tanggung jawab negara sebagai: “...kewajiban memberikan jawaban yang merupakan perhitungan atas suatu hal yang terjadi dan kewajiban untuk memberikan pemulihan atas kerugian yang mungkin ditimbulkannya."14 Secara historis prinsip tanggung jawab negara memiliki kaitan erat dengan HAM melalui prinsip tanggung jawab

6 Pocut Eliza dkk., Kelompok Kerja Analisis dan Evaluasi Hukum dalam Rangka Membangun Sistem Hukum Pidana Anak, Jakarta: BPHN, 2016, hlm. 2. Lihat juga dalam Gilang Ramadhan Suharto, "Restorative Justice Peradilan Pidana Anak di Indonesia", Lex Crimen Volume IV, Nomor 1, Januari-Maret 2015, hlm. 35.

7 Rahayu, Hukum Hak Asasi Manusia, Semarang: Badan Penerbit Universitas diponegoro, 2015, hlm. 13. Lihat dalam Setiyani, Joko Setiyono, "Penerapan Prinsip Pertanggungjawaban Negara terhadap Kasus Pelanggaran HAM Etnis Rohingya di Myanmar", Jurnal Pembangunan Hukum Indonesia, Volume 2, Nomor 2, Tahun 2020, hlm. 263.

8 Naya. A. Zaini, “Politik Hukum dan HAM", Jurnal Panorama Hukum, Volume 1, Nomor 2, 2016, hlm. 12.

9 Setiyani, Joko Setiyono, Loc. cit.

10 C. Philip, "Tanggung Jawab Negara terhadap Perlindungan HAM Menurut Hukum Internasional", Jurnal Lex Administratum, Volume 4, Nomor 2, 2016, hlm. 36.

11 Muhammad Luthfan Setiaji \& Aminullah Ibrahim, "Kajian HAM dalam Negara The Rule of Law", Lex Scientia Law Review, Volume 1, Nomor 1, 2017, hlm. 76.

12 Yunisa Sholikhati, Anak "Berkonflik dengan Hukum (ABH), Tanggung Jawab Orang Tua atau Negara?", Seminar Psikologi \& Kemanusiaan, Malang: Psychology Forum UMM, hlm. 465.

13 Arif Gosita, Masalah Perlindungan Anak; Kumpulan Karangan, Jakarta: PT Bhuana Ilmu Populer, 2004, hlm. 37. Lihat dalam Imam Sukadi, Op. cit., hlm. 120.

14 F. Sugeng Istanto, Hukum Internasional, Yogyakarta: Atma Jaya Yogyakarta, 1998, hlm. 77. 
negara atas perlakuan terhadap orang asing (state responsibility for the treatment of aliens). ${ }^{15}$ Dalam konteks penegakkan HAM, negara diberikan kewajiban melalui deklarasi dan kovenankovenan internasional tentang HAM sebagai entitas utama yang bertanggung jawab secara penuh untuk melindungi, menegakkan, dan memajukan HAM. ${ }^{16}$ Hal inilah yang melahirkan tanggung jawab negara dalam usaha perlindungan hak anak, termasuk hak Anak yang berkonflik dengan hukum (Undang-Undang Perlindungan Anak), ${ }^{17}$ perlindungan terhadap hak anak harus dikedepankan. ${ }^{18}$ Anak yang berkonflik dengan hukum adalah korban dari kondisi sosial dan permasalahan yang terjadi di keluarga maupun lingkungan sekitarnya. ${ }^{19}$

Penyimpangan tingkah laku atau perbuatan melanggar hukum yang dilakukan oleh anak, disebabkan faktor di luar diri anak tersebut. Data anak yang berhadapan dengan hukum dari Direktorat Jenderal Pemasyarakatan menunjukkan bahwa tingkat kriminalitas serta pengaruh negatif semakin meningkat. ${ }^{20}$ Kemudian ditunjukkan juga pada data Polda Metro Jaya periode 2013-2017 Ayu Eza Tiara menghitung ada 229 kasus anak yang berhadapan dengan hukum. Dari 229 kasus itu hanya 32 kasus yang diupayakan diversi pada tahap penyidikan dan 158 kasus tidak dilakukan diversi dan 39 kasus tidak diketahui apakah dilaksanakan diversi atau tidak. Kemudian, melalui Komisioner Komisi Perlindungan Anak Indonesia (KPAI), Putu Elvina, mengatakan periode 2017 KPAI menerima 3.849 kasus, dari jumlah itu kasus yang berkaitan dengan anak berhadapan dengan hukum paling banyak. ${ }^{21}$ Pada Sistem Database Pemasyarakatan (SDP) pada akhir November 2019 menunjukkan saat ini terdapat 1.737 anak pidana yang tersebar pada 33 (tiga puluh tiga) Lembaga Pembinaan Khusus Anak (LPKA) di seluruh Indonesia. ${ }^{22}$ Oleh karena itu, anak perlu mendapat pelindungan dari dampak negatif

15 Rhona K.M. Smith, Christian Ranheim dkk., Hukum Hak Asasi Manusia, Yogyakarta: PUSHAM UII, 2008, hlm. 81.

16 Muh. Yusuf, Tanggung Jawab Negara terhadap Hak Pendidikan Bagi Warga Negara Indonesia Berdasarkan UUD 1945, Makassar: Program Pascasarjana Universitas Hasanuddin 2013, hlm. 102.

17 Yunisa Sholikhati, Op. cit., hlm. 467.

18 PERMEN Pemberdayaan Perempuan dan Perlindungan Anak Republik Indonesia Nomor 15 Tahun 2010, Pedoman Umum Penanganan Anak yang Berhadapan dengan Hukum, Kementerian Pemberdayaan Perempuan dan Perlindungan Anak Republik Indonesia.

19 Melinda Maharani, Penerapan Diversi pada Kasus Anak yang Melakukan Pengulangan Tindak Pidana dan yang Melakukan Tindak Pidana yang Ancaman Pidana di Atas 7 (tujuh) Tahun, Yogyakarta: Program Studi Ilmu Hukum Fakultas Hukum Universitas Islam Indonesia, 2016, hlm. 4.

20 Lihat dalam Penjelasan Undang-Undang Nomor 11 tahun 2012 tentang Sistem Peradilan Pidana Anak.

21 "Mengenal Konsep Diversi dalam Pengadilan Pidana Anak", HukumOnline.com, https://www.hukumonline.com/berita/baca/lt5adeefc80f6ba/mengenal-konsep-Diversi-dalampengadilan-pidana-anak?page=3, 24 April 2018, diakses pada tanggal 21 November 2020.

22 "Status Pelaporan Klasifikasi Anak Perkanwil", Sistem Database Pemasyarakatan direktorat Jenderal Pemasyarakatan Kementerian Hukum dan HAM Republik Indonesia, http://smslap.ditjenpas.go.id/public/arl/current/monthly/year/2020/month/12, diakses pada tanggal 21 November 2020. 
perkembangan pembangunan, arus globalisasi, kemajuan ilmu pengetahuan dan teknologi, serta perubahan gaya dan cara hidup. ${ }^{23}$

\section{METODE PENELITIAN}

Penelitian ini adalah penelitian hukum normatif, yaitu penelitian yang dilakukan dengan menganalisis permasalahan dengan menggunakan asas-asas hukum dan prinsip-prinsip hukum. Peneliti menganalisis ketentuan-ketentuan yang menjadi dasar dan landasan bagi permasalahan yang dibahas dengan melakukan studi kepustakaan. Pendekatan penelitian hukum normatif yang digunakan adalah pendekatan perundang-undangan (statute approach), dan pendekatan konseptual (conceptual approach).

Teknik pengumpulan bahan hukum yang berkaitan dengan penelitian ini adalah studi kepustakaan (library research). Studi kepustakaan adalah suatu alat pengumpulan bahan hukum yang dilakukan melalui bahan hukum tertulis dengan mempergunakan content analysis. $^{24}$ Analisis bahan hukum yang digunakan adalah deskriptif analitis yaitu suatu penelitian yang bertujuan untuk mendeskripsikan tentang fakta dan kondisi atau gejala yang menjadi objek penelitian, setelah itu dilakukan telaah secara kritis, dalam arti memberikan penjelasan-penjelasan atas fakta atau gejala tersebut, baik dalam kerangka sistemisasi atau sinkronisasi, dengan berdasarkan pada aspek yuridis.

\section{ANALISIS DAN PEMBAHASAN}

Fungsi dan Wewenang Negara dalam Mewujudkan Perlindungan Terhadap Anak dalam

\section{Proses Diversi}

Hak Asasi Anak merupakan bagian dari hak asasi manusia yang termuat dalam Undang-undang Dasar Negara Republik Indonesia tahun 1945 dan Konvensi Perserikatan Bangsa-Bangsa tentang Hak-hak Anak. Ketentuan Pasal 28B ayat (2) Undang-Undang Dasar Negara Republik Indonesia menyebutkan bahwa setiap anak berhak atas kelangsungan hidup, tumbuh dan berkembang serta berhak atas perlindungan dari kekerasan dan diskriminasi.

Perlindungan anak terkait erat dengan lima pilar yakni, orang tua, keluarga, masyarakat, pemerintah, pemerintah daerah dan negara. Dalam bentuknya yang paling sederhana, perlindungan anak mengupayakan agar setiap hak anak tidak dirugikan. Perlindungan anak

23 Hafridaa dan Helmib, "Perlindungan Korban Melalui Kompensasi dalam Peradilan Pidana Anak", Jurnal Bina Mulia Hukum, Volume 5, Nomor 1, September 2020, hlm. 121.

24 Peter Mahmud Marzuki, Penelitian Hukum, Jakarta: Kencana Prenada Media Group, 2011, hlm. 21. 
bersifat melengkapi hak-hak lainnya menjamin bahwa anak-anak akan menerima apa yang mereka butuhkan agar mereka dapat bertahan hidup, berkembang dan tumbuh. ${ }^{25}$ Tugas pemerintah menurut Mac Iver yang digolongkan menjadi tiga yaitu: (1) cultural function; (2) general welfare function; dan (3) economic control function. ${ }^{26}$ Menurut S.F. Marbun, sifat wewenang pemerintahan yang jelas maksud dan tujuannya itu terikat pada waktu tertentu dan tunduk pada batasan-batasan hukum tertulis dan hukum yang tidak tertulis. Sedangkan isinya dapat bersifat umum (abstrak). ${ }^{27}$

Perlindungan anak sebagaimana batasan pengertian yang tercantum dalam Pasal 1 angka 2 Undang-Undang tentang Perlindungan Anak (UUPA) dapat terwujud apabila mendapatkan dukungan dan tanggung jawab dari berbagai pihak yang diatur dalam Pasal 20 UUPA. $^{28}$ Pengaturan mengenai kewajiban dan tanggung jawab negara dan pemerintah tercantum dalam pemberian jaminan perlindungan hak anak ini dikuatkan melalui pengesahan Konvensi Hak Anak melalui Keputusan Presiden Nomor 36 Tahun 1990 tentang Pengesahan Convention On The Rights of The Child (Konvensi Tentang Hak-Hak Anak), Undang-Undang Nomor 23 Tahun 2002 tentang Perlindungan Anak sebagaimana yang telah diubah dengan Undang-Undang Nomor 35 Tahun 2014 tentang Perubahan Atas Undang-Undang Nomor 23 Tahun 2002 tentang Perlindungan Anak, khususnya pada ketentuan Pasal 21, Pasal 22 Pasal 59 angka 2 .

Berdasarkan Pasal 59 Undang-Undang Nomor 23 Tahun 2002 tentang Perlindungan Anak dikatakan bahwa pemerintah dan lembaga negara lainnya berkewajiban dan bertanggung jawab untuk memberikan perlindungan khusus kepada anak dalam situasi darurat, anak yang berhadapan dengan hukum, anak dari kelompok minoritas dan terisolasi, anak tereksploitasi secara ekonomi dan/atau seksual, anak yang diperdagangkan, anak yang menjadi korban penyalahgunaan narkotika, alkohol, psikotropika, dan zat adiktif lainnya (napza), anak korban penculikan, penjualan dan perdagangan, anak korban kekerasan baik fisik dan/atau mental, anak yang mengandung cacat, dan anak korban perlakuan salah dan penelantaran.

Undang-Undang Nomor 11 Tahun 2012 tentang Sistem Peradilan Pidana Anak khususnya dalam hal pertanggungjawaban atas perbuatan pidana yang dilakukan oleh anak

25 Rini Fitriani, "Peranan Penyelenggara Perlindungan Anak dalam Melindungi dan Memenuhi Hak-hak Anak", Jurnal Hukum Samudra Keadilan, Volume 11, Nomor 2, Juli-Desember 2016, hlm. 251.

26 Irfan Fachruddin, Op. cit., hlm. 30.

27 Ibid., hlm. 154.

28 Winahyu Erwiningsih, "Peranan Hukum dalam Pertanggung-Jawaban Perbuatan Pemerintahan (Bestuurshandeling) Suatu kajian dalam Kebijakan Pembangunan Hukum", Jurisprudence, Volume 1, Nomor 2, September 2004, hlm. 140. 
dapat diminimalisasi dengan upaya diversi. Diversi adalah pengalihan penyelesaian perkara anak dari proses peradilan pidana ke proses di luar peradilan pidana yang bertujuan mencapai perdamaian antara korban dan anak, menyelesaikan perkara anak di luar proses peradilan, menghindarkan anak dari perampasan kemerdekaan, mendorong masyarakat untuk berpartisipasi dan menanamkan rasa tanggung jawab kepada anak. Proses diversi dilakukan melalui musyawarah dengan melibatkan anak dan orang tua/walinya, korban dan orang tua/walinya, pembimbing kemasyarakatan dan pekerja sosial profesional berdasarkan pendekatan keadilan restoratif. ${ }^{29}$ Proses ini bertujuan untuk menentukan tanggung jawab dan program rehabilitasi seperti apa yang sesuai dengan kebutuhan anak yang berhadapan dengan hukum tanpa membawa anak yang berhadapan dengan hukum ke proses peradilan pidana yang formal. ${ }^{30}$

Beberapa peraturan perundang-undangan tersebut bertujuan agar dapat terwujud peradilan yang benar-benar menjamin pelindungan kepentingan terbaik terhadap Anak yang berhadapan dengan hukum sesuai dengan Konvensi Hak-Hak Anak (Convention on the Rights of the Child) sebagaimana telah diratifikasi oleh Pemerintah Republik Indonesia dengan Keputusan Presiden Nomor 36 Tahun 1990 tentang Pengesahan Konvensi tentang Hak-Hak Anak), kemudian diubah menjadi Undang-Undang Nomor 11 tahun 2012 tentang Sistem Peradilan Pidana Anak. Kemudian dalam Peraturan Mahkamah Agung (PERMA) Nomor 4 Tahun 2014 tentang Pedoman Pelaksanaan Diversi dalam Sistem Peradilan Pidana Anak, dimana poin utamanya adalah hakim wajib menyelesaikan persoalan perlindungan anak-anak yang berhadapan dengan hukum $(\mathrm{ABH})$ dengan cara diversi. ${ }^{31}$ Di samping itu, PERMA ini merupakan pegangan hakim dalam penyelesaian tindak pidana anak sebelum adanya regulasi khusus mengenai diversi pada sistem pengadilan pidana terhadap anak dengan syarat bahwa tindak pidana yang dilakukan merupakan pelanggaran, tindak pidana ringan, tindak pidana tanpa korban maupun tindak pidana yang menyebabkan kerugian yang nilainya tidak melebihi dari nilai upah minimum provinsi setempat serta tindak pidana yang hukuman pidana penjaranya di bawah 7 (tujuh) tahun dan memiliki rentang usia tidak lebih dari 18 (delapan belas) tahun.

29 Yanse Oktaliza, "Analisis Yuridis Konsep Pertanggungjawaban Pidana terhadap Pembunuhan Berencana yang dilakukan Anak di Bawah Umur", Jurnal Ilmu Hukum Justicia Sains Vol 1, No 2, 2016, hlm. 73.

30 Chairul Bariah, Mohd. din, dan Mujibussalim, "Perluasan Pertanggungjawaban terhadap Tindak Pidana yang Dilakukan oleh Anak", Syiah Kuala Law Journal, Volume 1, Nomor 3 Desember 2017, hlm. 78.

31 Dhoni Martien, "Politik Hukum Penerapan Diversi pada Sistem Peradilan Pidana Anak Untuk Mewujudkan Keadilan Restoratif”, Jurnal Penelitian Hukum Legalitas, Volume 11, Nomor 1, Januari 2017, hlm. 12-13. 
United Nations Minimum Rules for the Administrator of Juveline (The Beijing Rules), memberikan pengertian diversi adalah pemberian kewenangan dari negara kepada aparat penegak hukum untuk mengambil tindakan-tindakan kebijaksanaan dalam menangani atau menyelesaikan masalah pelanggar anak dengan tidak mengambil jalan formal antara lain menghentikan atau meneruskan atau melepaskan dari proses peradilan pidana atau mengembalikan atau menyerahkan kepada masyarakat dan bentuk kegiatan pelayanan sosial lainnya. ${ }^{32}$ Adanya tujuan tersebut, maka negara bertanggung jawab untuk memenuhi kebutuhan dasar anak-anak yaitu kebutuhan yang layak bagi kemanusiaan, dan dalam pelaksaan pemeliharaan anak-anak di Indonesia dilakukan dengan memberikan hak-haknya secara normal layaknya anak-anak pada umumnya yaitu hak sipil dan hak kemerdekaan, lingkungan keluarga dan pilihan pemeliharaan, kesehatan dasar dan kesejahteraan, pendidikan, rekreasi dan budaya serta asuhan, perawatan dan pembinaan. Secara legal formal fungsi negara melindungi anak dan adalah upaya negara terhadap masa depan anak melalui pembuatan kebijakan atau peraturan perundang-undangan. ${ }^{33}$ Berangkat dari fungsi inilah selanjutnya melahirkan suatu kewenangan yang mesti dilaksanakan oleh negara melalui organ pemerintahannya. Maka, kewenangan tidak hanya diartikan sebagai hak untuk melakukan praktik kekuasaan. Namun kewenangan juga diartikan untuk menerapkan dan menegakkan hukum; ketaatan yang pasti; perintah; memutuskan; pengawasan; yurisdiksi; atau kekuasaan. ${ }^{34}$ Istilah wewenang atau kewenangan secara konseptual sering disejajarkan dengan istilah Belanda "bevoegdheid" (wewenang atau berkuasa). Wewenang merupakan bagian yang sangat penting dalam Hukum Tata Pemerintahan (hukum administrasi), karena pemerintahan baru dapat menjalankan fungsinya atas dasar wewenang yang diperolehnya. ${ }^{35}$

Teori Kewenangan sebagai middle theory menurut Philipus M. Hadjon, kewenangan dapat diperoleh melalui tiga sumber, yaitu atribusi, delegasi, dan mandat. Jika dianalisis dengan teori kewenangan dari Philipus M. Hadjon adalah, bahwa yang melaksanakan diversi pada Sistem Peradilan Pidana Anak adalah Penyidik Kepolisian, Jaksa Penuntut Umum dan Hakim. ${ }^{36}$ Maka, kewenangan menjatuhkan sanksi pidana itu adalah negara. Diversi merupakan kebijakan

32 Wijoyo R, Sistem Peradilan Pidana Anak di Indonesia, Jakarta: Sinar Grafika, 2015. hlm. 47-48.

33 Triyani Kathrilda Ambat, "Fungsi Negara Memelihara Anak-anak Terlantar Menurut Undang-Undang Dasar 1945”, Lex Administratum, Volume 1, Nomor 2, Januari-Maret 2013, hlm. 1.

34 Salim H.S dan Erlies Septiana Nurbani, Penerapan Teori Hukum pada Penelitian Tesis dan Disertasi, Jakarta: Rajawali Pers, 2013, hlm. 185.

35 SF. Marbun, Peradilan Administrasi Negara dan Upaya Administrasi di Indonesia, Yogyakarta: Liberty, 1997, hlm. 154.

36 Dhoni Martien, Op. cit., hlm. 12-13. 
yang dilakukan untuk menghindarkan pelaku dari sistem peradilan pidana formal. ${ }^{37}$ Maka melalui undang-undang, negara menunjuk pejabat tertentu untuk menjatuhkan sanksi pidana kepada pelaku kejahatan. 38

Undang-Undang Nomor 11 Tahun 2012 adalah wujud dari politik hukum pemerintah untuk merealisasikan keseriusan pemerintah dalam perkara pidana anak dimana undangundang tersebut dinamakan SPPA yaitu Sistem Peradilan Pidana Anak, sebagaimana diletakkan dalam ketentuan Pasal 1. ${ }^{39}$ Sistem Peradilan Pidana Anak merupakan segala unsur sistem peradilan pidana yang terkait dalam penanganan kasus-kasus ABH (Anak Bermasalah dengan Hukum), antara lain: Polisi, Kejaksaan dan Pengadilan serta pembimbing Kemasyarakatan atau Balai Pemasyarakatan, Advokat atau pemberi bantuan, Lembaga Pembinaan Khusus Anak (LPKA), Lembaga Penempatan Anak Sementara (LPAS), dan Lembaga Penyelenggaraan Kesejahteraan Sosial (LPKS) sebagai institusi atau lembaga yang menangani ABH mulai dari anak bersentuhan dengan sistem peradilan, menentukan apakah anak akan ditempatkan dalam pilihan-pilihan mulai dari dibebaskan sampai dimasukkan dalam institusi penghukuman dalam koridor keadilan restoratif. ${ }^{40}$ Terkait dengan kekhususan dalam penanganan anak yang berkonflik dengan hukum ada 7 (tujuh) pilar peradilan anak yaitu Polisi, Advokat, Jaksa, Hakim (Pengadilan), Petugas Bapas, Petugas Lembaga Pemasyarakatan dan Warga Masyarakat.41 Ketujuh komponen ini diharapkan bekerja sama membentuk apa yang dikenal dengan intergrated criminal justice system.

Prinsip utama pelaksanaan diversi adalah tindakan persuasif atau dikenal juga dengan pendekatan non-penal dengan memberikan kesempatan kepada seseorang untuk memperbaiki kesalahan. ${ }^{42}$ Sehingga, pelaksanaan diversi pada tahap penyidikan memberikan ruang untuk menjamin keadilan hukum terhadap anak. ${ }^{43}$ Berdasarkan Undang-Undang Nomor 11 Tahun 2012 tentang Sistem Peradilan Pidana Anak Pasal 29 menyatakan diversi hanya dapat dilaksanakan ancaman tindak pidana di bawah 7 (tujuh) tahun atau diklasifikasikan ke dalam

37 Fiska Ananda, "Penerapan Diversi Sebagai Upaya Perlindungan Hukum terhadap Anak Pelaku Tindak Pidana”, Jurnal Daulat Hukum, Volume 1, Nomor 1, Maret 2018, hlm. 79.

38 Dhoni Martien, Op. cit., hlm. 13.

39 Ibid., hlm. 9.

40 Hulman Panjaitan Lonna Yohanes Lengkong Fabianustua Sihaloho, "Penerapan Diversi terhadap Anak yang Melakukan Tindak Pidana”, Tô-râ: Volume 5, Nomor 2, Agustus 2019, hlm. 97.

41 Rendy H. Pratama, Sri Sulastri, \& Rudi Saprudin Darwis, "Perlindungan terhadap Anak yang Berhadapan dengan Hukum”, Prosiding KS: Riset \& PKM, Volume 2, Nomor 1, hlm. 12.

42 Azwad Rachmat Hambali, "Penerapan Diversi terhadap Anak yang Berhadapan dengan Hukum dalam Sistem Peradilan Pidana”, Jurnal Ilmiah Kebijakan Hukum Volume 13, Nomor 1, Maret 2019, hlm. 22.

43 Maya Sari, Made Ayu Citra, "Diversi dalam Sistem Peradilan Pidana Anak di Indonesia”, Artikel Hukum dan Sistem Peradilan Pidana, Denpasar: Pascasarjana Universitas Udayana, 2012, hlm. 7. 
tindak pidana ringan, tanpa memberikan aturan perlindungan ancaman tindak pidana di atas 7 (tujuh) tahun. Tidak konsisten dalam pelaksanaan diversi terhadap ancaman tindak pidana di atas 7 (tujuh) tahun secara prinsip membuat perlindungan hukum terhadap anak masih belum maksimal sedangkan yang terancam hukuman di atas 7 (tujuh) tahun tetap diproses secara formal.

Penegak hukum dalam praktiknya, Kepolisian (penyidik) berwenang menentukan posisi anak pelaku tindak pidana untuk tidak meneruskan atau memberhentikan perkara anak pelaku tindak pidana atau melakukan diversi terhadap anak pelaku tindak pidana. Berdasarkan Pasal 7 ayat (1) huruf j Undang-Undang Nomor 8 Tahun 1981 tentang Hukum Acara Pidana, dan Pasal 16 Ayat (1) huruf 1 Undang-Undang Nomor 2 tahun 2002 Tentang Kepolisian Republik Indonesia. Pelaksanaan diversi pada tahap penyidikan dapat dilakukan dengan cara musyawarah yang melibatkan anak dan orang tua/walinya, korban dan/atau orang tua/walinya, pembimbing kemasyarakatan dan pekerja sosial profesional berdasarkan pendekatan keadilan restoratif. ${ }^{44}$ Selanjutnya, Pasal 8 dan Pasal 29 ayat (3) Undang-Undang Nomor 11 tahun 2012 tentang Sistem Peradilan Pidana Anak penghentian penyidikan terhadap anak pelaku tindak pidana dapat dilakukan apabila penetapan hasil kesepakatan diversi telah disampaikan oleh pembimbing kemasyarakatan ke Pengadilan Negeri untuk dibuatkan penetapan. 45 Penanganan anak bermasalah dengan hukum (ABH) melalui tindakan diversi sebagai upaya untuk mewujudkan keadilan, walaupun menurut Mochtar Kusumaatmadja dan B. Arief Sidharta ${ }^{46}$ dikatakan bahwa keadilan adalah suatu yang sukar didefinisikan, tetapi dapat dirasakan dan merupakan unsur yang tidak dapat dipisahkan dari hukum sebagai perangkat asas dan kaidah yang menjamin adanya keteraturan dan ketertiban dalam masyarakat. Berhukum dengan hati hakikatnya memadukan rasio dengan akhlak dalam aktualisasi hukum dalam masyarakat. ${ }^{47}$

\section{Peran Negara Mewujudkan Perlindungan Terhadap Anak dalam Proses Diversi}

\footnotetext{
44 Pasal 1 ayat (6) Undang-Undang Nomor 11 tahun 2012 menyatakan keadilan restoratif justice adalah penyelesaian perkara tindak pidana dengan melibatkan pelaku, korban keluarga pelaku/korban dan pihak lain yang terkait untuk bersama-sama mencari penyelesaian yang adil dengan menekan pemulihan kembali pada keadaan semula dan bukan pembalasan.

45 Fiska Ananda, Op. cit., hlm. 81-82.

46 Mochtar Kusumaatmadja dan B. Arief Sidharta, Pengantar Ilmu Hukum, Suatu Pengenalan Pertama Ruang Lingkup Berlakunya Hukum. Buku I, Bandung: Alumni, 2000, hlm. 52.

47 Absori, Pemikiran Hukum Transendental dalam Konteks Pengembangan Ilmu Hukum Indonesia dalam Transedensi Hukum: Prospek dan Implementasi, Yogyakarta: Genta Publishing, 2017, hlm. 1.
} 
Posisi seorang anak merupakan generasi penerus bangsa, oleh sebab itu untuk menjaga harkat dan martabatnya, anak berhak mendapatkan pelindungan khusus, terutama pelindungan hukum dalam sistem peradilan. Salah satu upaya pencegahan dan penanggulangan terhadap anak yang berhadapan dengan hukum saat ini melalui penyelenggaraan Sistem Peradilan Pidana Anak. Oleh karena itu, ketentuan mengenai penyelenggaraan pengadilan bagi anak perlu dilakukan secara khusus, ${ }^{48}$ yaitu dengan memberikan alternatif lain yang dianggap lebih baik untuk anak yang disebut dengan "diversi". Hal ini merupakan suatu keadaan dalam rangka penegakan hukum law enforcement terdapat kehendak agar hukum tegak, sehingga nilai-nilai yang diperjuangkan melalui instrumen hukum yang bersangkutan dapat diwujudkan, sebab hukum tersebut digunakan untuk membenarkan tindakan-tindakan yang dilakukan to use the law to legitimate their actions. ${ }^{49}$

Melalui Undang-Undang Nomor 3 Tahun 1997 tentang Pengadilan Anak, UndangUndang Nomor 39 tentang Hak Asasi Manusia dan Undang-Undang Nomor 23 Tahun 2002 tentang Perlindungan Anak, maka salah satu solusi yang dapat ditempuh dalam penanganan perkara tindak pidana anak adalah pendekatan restorative justice, yang dilaksanakan dengan cara pengalihan (diversi).50 Maka, hak dan kewajiban anak diatur dalam Pasal 4 sampai dengan Pasal 19 Undang-Undang Nomor 23 Tahun 2002 tentang Perlindungan Anak, sebagaimana dinyatakan juga dalam Pasal 52 ayat (2) Undang-Undang Nomor 39 Tahun 1999 tentang Hak Asasi Manusia. Serta, diversi dilakukan untuk memberikan perlindungan dan rehabilitasi (protection and rehabilitation) kepada pelaku sebagai upaya untuk mencegah anak menjadi pelaku kriminal dewasa. ${ }^{51}$ Beberapa prinsip terpenting dalam memberikan perlindungan terhadap anak, sebagai berikut: (1), prinsip non diskriminasi agar negara berkewajiban untuk melindungi dan menghormati hak-hak anak; (2), prinsip kepentingan yang terbaik bagi anak agar perlindungan anak terselenggara dengan baik; Prinsip (3), hak hidup, kelangsungan hidup, dan perkembangan; dan Prinsip (4), penghargaan terhadap pendapat anak. ${ }^{52}$ Pandangan tersebut sejalan dengan pendapat dari Plato bahwa penyelenggaraan negara yang baik ialah

48 Mohammad Taufik Makarao dkk., Hukum Perlindungan Anak dan Penghapusan Kekerasan dalam Rumah Tangga, Jakarta: Rineka Cipta, 2013, hlm. 1.

49 Oheo K. Haris, "Telaah Yuridis Penerapan Sanksi di Bawah Minimum Khusus pada Perkara Pidana Khusus”, Jurnal Ius Constituendum, Volume 2, Nomor 2, Tahun 2017, hlm. 241.

50 Fiska Ananda, Op. cit., hlm. 78-79.

51 Yati Sharfina Desiandri, "Diversi terhadap Anak yang Berkonflik dengan Hukum di Tingkat Penyidikan”, USU Law Journal, Volume 5, Nomor 1, Januari 2017, hlm. 147-157.

52 Reza Fahlevi, “Aspek Hukum Perlindungan Anak dalam Perspektif Hukum Nasional”, Lex Jurnalica, Volume 12 Nomor 3, Desember 2015, hlm. 179. 
yang didasarkan pada pengaturan (hukum) yang baik.53 Kehadiran negara dan pemerintah untuk memberikan perlindungan kepada anak sebagai salah satu organ penyelenggara negara mempunyai tanggung jawab terhadap pemeliharaan dan pembinaan anak-anak yang bermasalah dengan hukum $(\mathrm{ABH})$.

\section{KESIMPULAN}

Fungsi dan wewenang negara dalam mewujudkan perlindungan terhadap anak dalam proses diversi sebagai tugas negara yang telah menjamin terhadap hak setiap anak atas kelangsungan hidup, tumbuh dan berkembang serta hak atas perlindungan dari kekerasan dan diskriminasi guna menghindarkan dan menjauhkan anak dari proses peradilan. Peran negara mewujudkan perlindungan terhadap anak dalam proses diversi telah dilaksanakan dimana setiap anak yang berhadapan dengan hukum berhak untuk mendapat perlindungan, baik fisik, mental, spiritual maupun sosial dengan perlu memperhatikan prinsip-prinsip Konvensi Hak Anak dan UndangUndang Perlindungan Anak.

\section{Daftar Pustaka}

\section{Buku}

Absori, Pemikiran Hukum Transendental dalam Konteks Pengembangan Ilmu Hukum Indonesia dalam Transedensi Hukum: Prospek dan Implementasi, Yogyakarta: Genta Publishing, 2017.

Eliza, Pocut, dkk., Kelompok Kerja Analisis dan Evaluasi Hukum dalam Rangka Membangun Sistem Hukum Pidana Anak, Jakarta: BPHN, 2016.

Fachruddin, Irfan, Pengawasan Peradilan Administrasi terhadap Tindakan Pemerintah, Bandung: PT. Alumni, 2004.

Gosita, Arif, Masalah Perlindungan Anak; Kumpulan Karangan, Jakarta: PT Bhuana Ilmu Populer, 2004.

H.S., Salim dan Erlies Septiana Nurbani, Penerapan Teori Hukum pada Penelitian Tesis dan Disertasi, Jakarta: Rajawali Pers, 2013.

Huda, Ni'matul, Negara Hukum, Demokrasi dan Judicial Review, Yogyakarta: UII Press, 2005. Istanto, F. Sugeng, Hukum Internasional, Yogyakarta: Atma Jaya Yogyakarta, 1998.

\footnotetext{
53 Ni'matul Huda, Negara Hukum, Demokrasi dan Judicial Review, Yogyakarta: UII Press, 2005, hlm. 1. Lihat juga dalam Markus Iman Sucipto, Guasman Tatawu, Muhammad Sabaruddin Sinapoy, "Kewenangan Biro Hukum Sekretariat Daerah Provinsi Sulawesi Tenggara dalam Penyelesaian Perkara Litigasi di Lingkungan Pemerintah Daerah", Halu Oleo Legal Research, Volume 1, Nomor. 2, August 2019, hlm. 322.
} 
Kusumaatmadja, Mochtar dan B. Arief Sidharta, Pengantar Ilmu Hukum, Suatu Pengenalan Pertama Ruang Lingkup Berlakunya Hukum. Buku I, Bandung: Alumni, 2000.

Maharani, Melinda, Penerapan Diversi pada Kasus Anak yang Melakukan Pengulangan Tindak Pidana danyang Melakukan Tindak Pidana yang Ancaman Pidana di Atas 7 (tujuh) Tahun,

Yogyakarta: Program Studi Ilmu Hukum Fakultas Hukum Universitas Islam Indonesia, 2016.

Makarao, Mohammad Taufik, dkk., Hukum Perlindungan Anak dan Penghapusan Kekerasan dalam Rumah Tangga, Jakarta: Rineka Cipta, 2013.

Marbun, SF., Peradilan Administrasi Negara dan Upaya Administrasi di Indonesia, Yogyakarta: Liberty, 1997.

Marlina, Peradilan Pidana Anak di Indonesia, Pengembangan Konsep Diversi dan Restorative Justice, Medan: Refika Aditama, 2012.

Marzuki, Peter Mahmud, Penelitian Hukum, Jakarta: Kencana Prenada Media Group, 2011.

Prakoso, Abintoro, Pembaruan Sistem Peradilan Pidana Anak, Surabaya: Laksbang Grafika, 2013.

Rahayu, Hukum Hak Asasi Manusia, Semarang: Badan Penerbit Universitas Diponegoro, 2015.

Smith, Rhona K.M., Christian Ranheim dkk., Hukum HakAsasi Manusia, Yogyakarta: PUSHAM UII, 2008.

Wijoyo, R, Sistem Peradilan Pidana Anak di Indonesia, Jakarta: Sinar Grafika, 2015.

Yusuf, Muh., Tanggung Jawab Negara terhadap Hak Pendidikan Bagi Warga Negara Indonesia Berdasarkan UUD 1945, Makassar: Program Pascasarjana Universitas Hasanuddin 2013.

\section{Jurnal dan Makalah}

Ambat, Triyani Kathrilda, "Fungsi Negara Memelihara Anak-anak Terlantar Menurut UndangUndang Dasar 1945”, Lex Administratum, Volume 1, Nomor 2, Januari-Maret 2013.

Ananda, Fiska, "Penerapan Diversi Sebagai Upaya Perlindungan Hukum terhadap Anak Pelaku Tindak Pidana”, Jurnal Daulat Hukum, Volume 1, Nomor 1, Maret 2018.

Bariah, Chairul, Mohd. din, dan Mujibussalim, "Perluasan Pertanggungjawaban terhadap Tindak Pidana yang Dilakukan oleh Anak", Syiah Kuala Law Journal, Volume 1, Nomor 3 Desember 2017.

Desiandrim Yati Sharfina, “Diversi terhadap Anak yang Berkonflik dengan Hukum di Tingkat Penyidikan”, USU Law Journal, Volume 5, Nomor 1, Januari 2017. 
Erwiningsih, Winahyu, "Peranan Hukum dalam Pertanggung-Jawaban Perbuatan Pemerintahan (Bestuurshandeling) Suatu kajian dalam Kebijakan Pembangunan Hukum", Jurisprudence, Volume 1, Nomor 2, September 2004.

Fahlevi, Reza, “Aspek Hukum Perlindungan Anak dalam Perspektif Hukum Nasional”, Lex Jurnalica, Volume 12 Nomor 3, Desember 2015.

Fitriani, Rini, “Peranan Penyelenggara Perlindungan Anak dalam Melindungi dan Memenuhi Hakhak Anak", Jurnal Hukum Samudra Keadilan, Volume 11, Nomor 2, Juli-Desember 2016.

Hafridaa dan Helmib, "Perlindungan Korban Melalui Kompensasi dalam Peradilan Pidana Anak", Jurnal Bina Mulia Hukum, Volume 5, Nomor 1, September 2020.

Hambali, Azwad Rachmat, "Penerapan Diversi terhadap Anakyang Berhadapan dengan Hukum dalam Sistem Peradilan Pidana", Jurnal Ilmiah Kebijakan Hukum Volume 13, Nomor 1, Maret 2019.

Haris, Oheo K., “Telaah Yuridis Penerapan Sanksi di Bawah Minimum Khusus pada Perkara Pidana Khusus", Jurnal Ius Constituendum, Volume 2, Nomor 2, Tahun 2017.

Martien, Dhoni, "Politik Hukum Penerapan Diversi pada Sistem Peradilan Pidana Anak Untuk Mewujudkan Keadilan Restoratif", Jurnal Penelitian Hukum Legalitas, Volume 11, Nomor 1, Januari 2017.

Oktaliza, Yanse, “Analisis Yuridis Konsep Pertanggungjawaban Pidana terhadap Pembunuhan Berencana yang dilakukan Anak di Bawah Umur", Jurnal Ilmu Hukum Justicia Sains Vol 1, No 2, 2016.

Panjaitan, Hulman, Lonna Yohanes Lengkong, Fabianustua Sihaloho, "Penerapan Diversi terhadap Anak yang Melakukan Tindak Pidana", Tô-râ: Volume 5, Nomor 2, Agustus 2019.

Philip, C., "Tanggung Jawab Negara terhadap Perlindungan HAM Menurut Hukum Internasional”, Jurnal Lex Administratum, Volume 4, Nomor 2, 2016.

Pratama, Rendy H., Sri Sulastri, \& Rudi Saprudin Darwis, “Perlindungan terhadap Anak yang Berhadapan dengan Hukum”, Prosiding KS: Riset \& PKM, Volume 2, Nomor 1.

Sari, Maya, Made Ayu Citra, “Diversi dalam Sistem Peradilan Pidana Anak di Indonesia”, Artikel Hukum dan Sistem Peradilan Pidana, Denpasar: Pascasarjana Universitas Udayana, 2012.

Setiaji, Muhammad Luthfan \& Aminullah Ibrahim, "Kajian HAM dalam Negara The Rule of Law", Lex Scientia Law Review, Volume 1, Nomor 1, 2017. 
Setiyani, Joko Setiyono, "Penerapan Prinsip Pertanggungjawaban Negara terhadap Kasus Pelanggaran HAM Etnis Rohingya di Myanmar", Jurnal Pembangunan Hukum Indonesia, Volume 2, Nomor 2, Tahun 2020.

Sholikhati, Yunisa, Anak "Berkonflik dengan Hukum (ABH), Tanggung Jawab Orang Tua atau Negara?”, Seminar Psikologi \& Kemanusiaan, Malang: Psychology Forum UMM.

Sucipto, Markus Iman, Guasman Tatawu, Muhammad Sabaruddin Sinapoy, "Kewenangan Biro Hukum Sekretariat Daerah Provinsi Sulawesi Tenggara dalam Penyelesaian Perkara Litigasi di Lingkungan Pemerintah Daerah", Halu Oleo Legal Research, Volume 1, Nomor. 2, August 2019.

Suharto, Gilang Ramadhan, "Restorative Justice Peradilan Pidana Anak di Indonesia”, Lex Crimen Volume IV, Nomor 1, Januari-Maret 2015.

Sukadi, Imam, “Tanggung Jawab Negara terhadap Anak Terlantar dalam Operasionalisasi Pemerintah di Bidang Perlindungan Hak Anak", de Jure, Jurnal Syariah dan Hukum, Volume 5 Nomor 2, Desember 2013.

Zaini, Naya. A., "Politik Hukum dan HAM", Jurnal Panorama Hukum, Volume 1, Nomor 2, 2016.

\section{Peraturan Perundang-undangan}

Undang-Undang Dasar Negara Republik Indonesia Tahun 1945.

Undang-Undang Nomor 39 Tahun 1999 Tentang Hak Asasi Manusia.

Undang-Undang Nomor 23 Tahun 2002 Tentang Perlindungan Anak.

Undang-Undang Nomor 11 tahun 2012 Tentang Sistem Peradilan Pidana Anak.

Undang-Undang Nomor 35 Tahun 2014 Tentang Perubahan Atas Undang-Undang Nomor 23 Tahun 2002 Tentang Perlindungan Anak.

Peraturan Pemerintah Nomor 43 Tahun 2017 Tentang Pelaksanaan Restitusi Bagi Anak Korban Tindak Pidana.

\section{Situs Web}

"Mengenal Konsep Diversi dalam Pengadilan Pidana Anak", HukumOnline.com, https://www.hukumonline.com/berita/baca/lt5adeefc80f6ba/mengenal-konsepDiversi-dalam-pengadilan-pidana-anak?page=3, 24 April 2018, diakses pada tanggal 21 November 2020.

"Status Pelaporan Klasifikasi Anak Perkanwil", Sistem Database Pemasyarakatan direktorat Jenderal Pemasyarakatan Kementerian Hukum dan HAM Republik Indonesia, 
http://smslap.ditjenpas.go.id/public/arl/current/monthly/year/2020/month/12, diakses pada tanggal 21 November 2020. 